INTERNATIONAL JOURN AL OF RESEARCHES IN BIOSCIENCES, AGRICULTURE AND TECHNOLOGY (c) VISHWASHANTI MULTIPURPOSE SOCIETY (Global Peace Multipurpose Socie ty) R. No. MH-659/13 (N) www.vmsindia.org

\title{
FRESHWATER HIGHER FUNGI FROM AHMEDNAGAR DISTRICT (M.S., INDIA) - II: ASCOMYCETES
}

\author{
D. S. Borade ${ }^{1}$, P. K. Ahire ${ }^{2}$, P. E. Jagdale ${ }^{3}$ and B. D. Borse ${ }^{4}$ \\ ${ }^{1}$ M. V. P. Ssamj's Arts, Sci. \& Comm. college, Ozar (Mig), Nashik (M.S). \\ ${ }^{2}$ K. A. M. Patil Arts, Comm. \& Sci. college, Pimpalner, Dhule (M.S.). \\ ${ }^{3}$ Arts, Sci. \& Comm. college, Rahuri, Dist.- Ahme dnagar (M.S.). \\ 4 N. S. Sanstha Dhule's, Utaamrao Patil Arts \& Sci. college, Dahiwel, Dhule (M.S.) \\ borsebdbot@rediffmail.com
}

\begin{abstract}
:
The present paper deals with 18 species of freshwater Ascomyce tes encountered on submerged decaying woody debris and leaves of Typha angustata Chaub. and Bory from lotic and lentic habitats in Ahmednagar district (Maharashtra state). These include species of the genera: Aniptodera (2 sp.), Annulatascus (2 sp.), Ascosacculus (1 sp.), Cercophora (1 sp.), Natantispora (1 sp.), Neomassariosphaeria (1 sp.), Panorbis (1 sp.), Paoayensis (1 sp.), Savoryella (6 sp.) and Zopfiella $(2 \mathrm{sp}$.). The data provides information on the distribution of these fungi in India, apart from description and illustrations. This data will be useful in the compilation of freshwater biodiversity of India. The taxonomy, morphology and ecology of these fungi are discussed.
\end{abstract}

Keywords: Ascomycetes, Freshwater, Submerged wood, Typhas p.

\section{Introduction:}

Freshwater Ascomycetes (FWA) are defined as Ascomycetous fungi which have been recorded in freshwater habitats and which complete part, or the whole of their lifecycle within freshwater environments (Shearer, 1993; Thomas, 1996; Wong et al., 1998a; Luo et al., 2004). Lignicolous FWA inhabit submerged woody material in lentic (lakes, ponds, etc.) and lotic (rivers, streams, etc.) habitats, playing an important role in recycling organic matter in the freshwater ecosystems. The FWA is one of the least studied groups of fungi. Although sporadic reports of Ascomycetous fungi that colonize freshwater macrophytes occur in the early Ascomycete systematic lite rature. Late Prof. C.T. Ingold was the first to recognize that a distinctive FWA might exist and published a series of papers on FWA from submerged substrates in the Lake District, England (Ingold 1951, 1954, 1955; Ingold and Chapman, 1952).

Until the end of last decade, FWA have been studied mainly including Australia, Brunei, China, Hong Kong, Malaysia, USA, and UK (Zhang et al., 2011; Jones et al., 2014). In India, previous studies on FWA were made by Manoharachary and Rama Rao (1972), Manoharachary (1972), Tilak and Kulkarni (1974), Natarajan and Udaiyan (1978), Udaiyan (1989), Udaiyan and Hosogaudar (1991), Agarwal et al. (1991), Ramesh (2002), Ramesh and Vijaykumar (2000, 2004, 2005, 2006), Borse and Pawara (2007), Sridhar et al. (2010, $2011 a)$, Sudheep and Sridhar (2011), Patil (2012a), Patil and Borse (2011a, 2012a, b), Upadhyaya et al. (2012), Borse et al. (2014a, 2014b, 2015) and Borse and Patil (2015). The objective of the present study was to study the diversity of FWA from Ahmednagar district of Maharashtra state. In the present paper 18 species (Table 2) of FWA collected on submerged decaying woody debris and leaves of Typha angustata Chaub. and Bory from lotic (streams, rivers etc.) and lentic (lakes, dams e tc.) habitats were briefly described and illustrated. The most specious genus encountered is Savoryella with 6 species.

\section{Materials and Methods:}

Sample of submerged decaying woody debris and leaves of Typha sp. were collected from various localities along rivers such as Mula, Pravara, Godavari, Sina, Bhima, Kukadi, Mohata, Ghod and reservoirs such as Bhandardara, Dnyaneshwarsagar, and Nathasagar. The survey was undertaken for four years during 2011-2014. The samples were analyzed by wood analysis method. Samples were collected and placed in polythe ne bags and transported to the laboratory. Samples contaminated by sediments or fouling organisms were washed with tap water and observed for Ascocarps. After initial observations, samples were incubated in sterile plastic boxes containing layer of blotting paper or ste rile sand moistened with sterile water. A few Naphthalene balls were placed in suitable containe $r$ inside of plastic box, to kill any insect in the wood. Distill water was added as if necessary to prevent the substratum form drying out. The water was 
sprayed on samples with a fine ae rosol spray. Plastic boxes tied with rubber band and placed in polythene bags to conserve a humid atmosphere within boxes. All samples were examined periodically and remoistened whenever necessary and after three weeks examined for the presence of fruiting bodies / Ascocarps. Semi-permanent slides of fungi isolated were made for further observations.

Samples were observed initially under 30 $X$ magnifying hand lens. Ascocarps then removed from the wood sample with fine pair of forceps or needle with a fine point. Ascocarps were mounted in the first instant in water, so that any appendages present on ascospores can get dilated and their true morphology determined. If ascospores are mounted directly in lacto - phenol, may lead to misidentification of the species. Semi-permanent mount of the fungi were made by replacing the Lacto phenol (with or without Cotton Blue) in place of water, by placing a drop of the mounting fluid to one side of the cover glass so that it sweeps under the cover glass. Excess mounting medium was cleaned through blotting paper. The cover glass was sealed with D.P.X. for temporary mounts. Permanent voucher slides of fungi were prepared according to the method 'double cover glass' described by Volkmann-Kohlmeyer and Kohlmeye r (1996).

\section{TAXONOMIC ACCOUNT}

1) Aniptodera chesapeakensis Shearer \& M.A. Miller, Mycologia, 69: 894 (1977); (Fig. 1).

Ascomata: 150-225 $\mu \mathrm{m}$ high, 200-300 $\mu \mathrm{m}$ in diam.; Asci: 120 x 15-35 $\mu \mathrm{m}$; Ascospores: 23-35 x 8-15 $\mu \mathrm{m}, 2-3$-seriate, ellipsoidal or fusiform, 1 euseptate, not constricted at the septum, hyaline, smooth, thick-walled, guttulate, with or without polar appendages; appendages filame ntous, unfurling in water, long or short.

Habitat: On submerged wood, Mula Dam, Mula River, Rahur, 22 Feb. 2012.

Distribution in India:-

Marine Habitats: West Coast.- Maharashtra, Goa, Karnataka, Pondecherry (Mahe); East Coast:- Tamil Nadu, Andhara Pradesh, West Bengal, Andaman-Nicobar Islands (Borse et al., 2012, 2013).

Freshwater Habitats: Karnataka: (Ramesh and Vijaykumar, 2006; Sudheep and Sridhar, 201 1); Maharashtra: (Patil and Borse, 2012b).

2) Aniptodera inflatiascigera K.M. Tsui, K.D. Hyde \& I.J. Hodgkiss, Sydowia, 49: 187-192 (1997); (Fig. 2)
Ascomata: 180-300 $\mu \mathrm{m}$ in diam.; Asci: 135-200 x 15-35 $\mu \mathrm{m}$; Ascospores: $35-40$ x 15-20 $\mu \mathrm{m}$, hyaline, ellipsoidal, bicelled, not constricted at the septum, relatively thick-walled $(2-3 \mu \mathrm{m}$ thick), with or without polar appendages; delicate, released from the pores at the ascospore tips.

Habitat: On submerged wood, Bhandardara dam, Pravara river, 28 March 2011.

Distribution in India:- Maharashtra: (Borse and Patil, 2015).

3) Annulutascus hongkongensis W.H. Ho, Ranghoo, K.D. Hyde \& I.J. Hodgkiss, Mycologia, 91: 886 (1999); (Fig.3)

Ascomata: 250-280 $\mu \mathrm{m}$ diam., 210-250 $\mu \mathrm{m}$ high; Asci: 250-275 x 25-30 $\mu \mathrm{m}$; Ascospores: 35-38 x 13-15 $\mu \mathrm{m}$, uniseriate or overlapping uniseriate, hyaline, ellipsoidal, 3-septate, guttulate, smooth, thin-walled with thick mucilaginous sheath (6-8 $\mu \mathrm{m}$ thick).

Habitat: On submerged wood, Bhandardara dam, Pravara river, 29 July 2012.

Distribution in India:- Maharashtra: (Borse et al., 2014a).

4) Annulatascus palmietensis Goh, K.D. Hyde \& Steinke, In: Hyde et al., S. Afr. J. Bot., 64: 151 (1998); (Fig. 4)

Ascomata: 250-400 $\mu \mathrm{m}$ diam.; Asci: 100-130 x 8-12 $\mu \mathrm{m}$; Ascospores: 20-25 x 6-7 $\mu \mathrm{m}, 1-2$ seriate, short fusiform, ends blunt, 3- septate in mature specimens, hyaline, appearing smoothwalled.

Habitat: On submerged wood, Bhandardara dam, Pravara river, 15 August 2013.

Distribution in India:- Maharashtra: (Borse et al., 2014a).

5) Ascosacculus heterogattulata (S.W. Wong, K.D. Hyde \& E.B.G. Jones) J. Campb., J.L. Anderson \& Shearer, Mycologia, 95: 545 (2003). = Halosarpheia heterogattulata S.W. Wong, K.D. Hyde \& E.B.G. Jones, Can. J. Bot, 76: 1858 (1998b). (Fig. 5);

Ascomata: 120-160 $\mu \mathrm{m}$ in diam.; Asci: 8spored, deliquescing early; Ascospores: 25-35 x 9-17 $\mu \mathrm{m}$, ellipsoidal, hyaline, 1-septate, equally two-celled, apical cell with one or two large lipid gattule(s), basal cell with numerous small gattules, with bipolar, hamate, and highly coiled filamentous appendages that unferl in water to form long strands.

Habitat: On submerged wood, Mula dam, Mula river, Rahuri, 28 August 2011. 
Distribution in India:- Karnataka: On submerged wood (Sridhar et al., 2011a); Maharashtra: (Borse and Patil, 2015).

6) Cercophora sp. (Fig. 6)

Ascomata: $1.5 \mathrm{~mm}$ in diam, $2.5 \mathrm{~mm}$ in high; Asci: when young cylindrical, 150-215 x 8-10 $\mu \mathrm{m}$, at maturity clavate, $120-130 \times 12-20 \mu \mathrm{m}$; Ascospores: cylindtrical, 43-48 x 4-5 $\mu \mathrm{m}$, sigmoid to geniculate, hyaline, aseptate, bipolar appendages long, 25-30 $\mu \mathrm{m}$, gelatinous, lashlike; becoming differentiated into an apical swollen head and a basal pedicel while inside the ascus; head ellipsoid, 12-18 x 8-10 $\mu \mathrm{m}$, conical at the apex, truncate at the base, hyaline; pedicel 20-30 $\mu \mathrm{m}$ long, $4.5 \mu \mathrm{m}$ in diam., up to 3 -septate, hyaline; ascospores up to 5-septate after liberation from the ascus.

Habitat: On wood in Jayakwadi dam, Godavari river, Deokane, 25 Sept. 2011.

7) Natantispora retorquens (Shearer \& J.L. Crane) J. Campb., J.L. Anderson \& Shearer Mycologia, 95: 543 (2003); = Halosarpheia retorquens Shearer \& J.L. Crane, Bot. Mar., 23: 608 (1980). (Fig. 7)

Ascomata: $140-325$ x 150-360 $\mu \mathrm{m}$.; Asci: 50-145 x 15-25 $\mu \mathrm{m}$; Ascospores: 20-35 x 7-12 $\mu \mathrm{m}$, ellipsoidal, hyaline, 1-septate, appendaged. Ap pendages: bipolar, composed of single, coiled or folded filament, at first hamate, finally unwinding in water to produce a long fine filame nt.

Habitat: On submerged wood, Bhandardara dam, Pravara river, 20 August 2012.

Distribution in India:- Marine Habitats:- West Coast:-Maharashtra, Karnataka, Kerala (Borse et al., 2012, 2013). Freshwater Habitats: Maharashtra: (Patil and Borse, 2012a).

8) Neomassariosphaeria typhicola (P. Karst.) Yin, Zhang, F. Fourn. \& K.D. Hyde, In: Zhang et al., Studies Mycology, 64: 96 (2009b); (Fig. 8)

Ascomata: 180-220 $\mu \mathrm{m}$ high, 200-425 $\mu \mathrm{m}$ diam.; Asci: $100-130$ x 20-25 $\mu \mathrm{m}$; Ascospores: 35-50 x 7-10 $\mu \mathrm{m}$, bi- or tri-seriate in the upper part of the ascus, uni-seriate below, fusiform, 7-11septate, slightly constricted at the septa, particularly around the thickest cell $\left(4^{\text {th }}\right.$ or $5^{\text {th }}$ from the top), straight or curved, at first hyaline, becoming light brown and verrucose in age, surrounded by a gelatinous, 2 to $4 \mu \mathrm{m}$ thick sheath.

Habitat:- On submerged decaying leaves of Typha angustata Chaub. and Bory, Mula river, Rahuri, 30 Septe mber 2011.
Distribution in India:- Marine waters: East Coast:- Andhara Pradesh: On intertidal wood of Rhizophora apiculata (Sarma and Vittal, 2004); Freshwater habitats: Maharashtra: (Borse and Patil, 2015).

9) Panorbis viscosus (I. Schmidt) J. Campb., J.L. Anderson \& Shearer, Mycologia, 95: 544 (2003); = Halosphaeria viscosus I. Schmidt, Natur und Natur. in Mecklenburg, 12: 70 (1974) 1979 and Mycotaxon, 24: 420 (1985); = Halosarpheia viscosus (I. Schmidt) Shearer \& J.L. Crane, Bot. Mar., 23: 608 (1980); (Fig. 9)

Ascomata: 200-450 x 200-385 $\mu \mathrm{m}$; Asci: 50-115 $\mathrm{x}$ 10-25 $\mu \mathrm{m}$; Ascospores: 15-26 x 5-8 $\mu \mathrm{m}$, hyaline, 1-septate, ellipsoidal, appendaged. Appendages: bipolar, composed of a single, coiled filament, at first hamate, unwinding in water to produce a long fine filament.

Habitat:- On submerged wood, Mula dam, Mula river, Rahuri, 30 September 2012.

Distribution in India:- Marine Habitats: We st Coast:- Maharashtra, Karnataka, Kerala; East Coast:- Tamil Nadu, Andhara Pradesh (see Borse et al., 2012; 2013); Freshwater Habitats: Maharashtra: On submerged wood (Patil and Borse, 2012a)

10) Paoayensis sp. (Fig. 10)

Ascomata: 700-1000 $\mu \mathrm{m}$ high, 800-1000 $\mu \mathrm{m}$ diam.; Asci: 85-170 × 40-65 $\mu \mathrm{m}$; Ascospores: 50$80 \times 20-38 \mu \mathrm{m}$, overlapping, le moniform,1-3septate, first septum formed near the base, second septum central, third septum near the rounded apex, brown, dark-brown at maturity, germ slit 10-12 $\mu \mathrm{m}$ long, not full le ngth, arising from the base, perpendicular to the ascospore, smooth-walled, and lacking a mucilaginous sheath.

Habitat: On submerged wood, Jayakwadi dam, Godavari river, Deokane, 15 Aug., 2012.

Remarks: The general characteristics of the present collection fit within the concept of the monotypic genus Paoayensis Cabanela et al. (2007). The present fungus differed markedly from the type species as provided in the table 1 . The ascomata and Asci of the present collection are larger than those of type species. Asci in the type species are 2-6 spores and 4-8 spored in the present collection. Ascospores of the type species are wider than the present collection. However, due to lack of material, cultural studies and molecular sequencing, the present collection was not described as new species.

11) Savoryella aquatica K.D. Hyde, Aust. Syst. Bot., 6: 162 (1993); (Fig. 11) 
Ascomata: 200-250 $\mu \mathrm{m}$ long, 100-125 $\mu \mathrm{m}$ diam.; Asci: $110-140$ x 25-35 $\mu \mathrm{m}$; Ascospores: $29-35$ x 13-17 $\mu \mathrm{m}$, ellipsoidal, central cells dark brown when mature, end cells hyaline, constricted weakly at the septa, central septa appearing as a band.

Habitat: On submerged wood, Bhandardara dam, Pravara river, 15 August 2014.

Distribution in India:- Maharashtra: On submerged wood (Borse and Pawara, 2007)

12) Savoryella fusiformis W.H. Ho, K.D. Hyde \& I.J. Hodgkiss, Mycol. Res., 101: 804 (1997); (Fig. 12)

Ascomata: 150-200 $\mu \mathrm{m}$ long, 70-90 $\mu \mathrm{m}$ diam.; Asci: 80-120 x 10-15 $4 \mathrm{~m}$; Ascospores: 25-35 x 6-9 $\mu \mathrm{m}$, fusiform, biseriate, 3-septate, slightly constricted at the septa, smooth, thin-walled; central cells brown, apical cells 4-5 $\mu \mathrm{m}$ long, 4$5 \mu \mathrm{m}$ wide, hyaline.

Habitat: On submerged wood, Mula dam, Mula river, Rahuri, 18 Augu st 2013.

Distribution in India:- Maharashtra: On submerged wood (Patil and Borse, 2011a)

13) Savoryella grandispora K.D. Hyde, Mycoscience, 35: 59-61 (1994b); (Fig. 13)

Ascomata: 200-260 $\mu \mathrm{m}$ long, 100-1125 $\mu \mathrm{m}$ diam.; Asci: 100-140 x 25-35 $\mu \mathrm{m}$; Ascospores: 45-60 x 14-16 $\mu \mathrm{m}$, ellipsoidal, biseriate, light brown, central cells dark brown when mature, end cells hyaline, constricted weakly at the septa.

Habitat:- On submerged wood, Bhandardara dam, Pravara river, 10 September 2013.

Distribution in India:- Maharashtra: On submerged wood (Patil and Borse, 2011a)

14) Savoryella lignicola E.B.G. Jones \& R.A. Eaton, Trans. Br. Mycol. Soc., 52: 162 (1969); (Fig. 14)

Ascomata: $200-340 \mu \mathrm{m}$ high, $120-180 \mu \mathrm{m}$ in diam.; Asci: 130-180 x 15-54 $\mu \mathrm{m}$; Ascospores: 25-35 x 9-13 $\mu \mathrm{m}$, uni or biseriate, ellip soidal, 3septate, not markedly constricted at the septa; central cells brown, apical cells smaller and hyaline.

Habitat: On submerged wood, Mula dam, Mula river, Rahuri, 10 September 2013.

Distribution in India:- Marine Habitats:- West Coast:-Daman, Gujarat, Goa, Karnataka, Pondeche rry (Mahe), Ke rala, Lakshadweep Islands; East Coast:-Tamil Nadu, Pondecherry, Andhara Pradesh, West Bengal, Andaman \& Nicobar Islands (see Borse et al., 2012; 2013).
Freshwater Habitats: Tamil Nadu: (Udaiyan, 1989; Udaiyan and Manian, 1991b); (Udaiyan and Manian, 1991a); Karnataka: (Ramesh and Vijaykumar, 2000; Ramesh and Vijaykumar, 2006; Sridhar et al., $2011 \mathrm{a}$; Sudheep and Sridhar, 2011); Maharashtra: (Borse and Pawara, 2007).

15) Savoryella limnetica H.S. Chang \& S.Y. Hsieh, Mycol. Res., 102: 715 (1998); $\quad$ (Fig. 15)

Ascomata: 250-300 x 160-200 $\mu \mathrm{m}$; Asci: 145$150 \times 10-12 \mu \mathrm{m}$; Ascospores: 20-25 x 7-9 $\mu \mathrm{m}$, ellipsoidal, 3-septate, not constricted, smooth, thin-walled, central cells brown, end cells smaller and hyaline to sub-hyaline.

Habitat:- On submerged wood, Bhandardara dam, Pravara river, 24 August 2014.

Distribution in India:- Maharashtra: On subme rged wood (Patil and Borse, 2011a)

16) Savoryella verrucosa Minoura \& $T$. Muroi, Trans. Mycol. Soc. Japan, 19: 132 (1978); (Fig. 16)

Ascomata: 250-325 $\mu \mathrm{m}$ long, 150-250 $\mu \mathrm{m}$ diam.; Asci: 170-200 x 22-35 $\mu \mathrm{m}$; Ascospores: 30-40 x 12-18 $\mu \mathrm{m}$, biseriate, ellispodal, 3septate when mature, constricted at the septa; central cells brown, distinctly verrucose, polar cells 3.8-6.4 $\mu \mathrm{m}$ long, 4-5 $\mu \mathrm{m}$ wide, hyaline.

Habitat:- On submerged wood, Mula dam, Mula river, Rahuri, 24 August 2014.

Distribution in India:- Karnataka: On submerged wood (Sridhar et al., 2011a); Maharashtra: On submerged wood (Patil and Borse and Patil, 2015).

17) Zopfiella karachiensis (S.L. Ahmed \& Asad) Guarro, In: Guarro and Cano, Trans. Br. Mycol. Soc., 91: 589 (1988); = Strattonia karachiensis S.L. Ahmed \& Asad, Sydowia, 21: 282 (1968); ” Podospora faurelii Mouchacca, Rev. Mycol., 38: 109 (1973); 三 Triangularia karachiensis (S.L. Ahmed \& Asad) Udagawa, Trans. Mycol. Soc. Japan, 20: 362-365 (1979); (Fig. 17)

Ascomata: 300-375 x 250-285 $\mu \mathrm{m}$; Asci 100$135 \times \quad 15-25 \mu \mathrm{m}$; Ascospores: biseriate, ellipsoidal, at first 1-celled, latter becoming 2celled, 35-40 x 12-20 $\mu \mathrm{m}$; upper cell dark olivaceous brown to dark brown, ellipsoid, inequilateral, smooth, with a single germ pore at the apex, 25-30 x 12-20 $\mu \mathrm{m}$; lower cell conical, hyaline often collapsed at maturity, 7 $10 \times 7-9 \mu \mathrm{m}$.

Habitat: On submerged wood, Bhandardara dam, Pravara river, 24 August 2014. 
Distribution in India:- Tamil Nadu: On wood test blocks (as Triangularia karachiensis, Udaiyan 1989; Udaiyan and Manian, 1991b); Maharashtra: (Borse and Patil, 2015).

18) Zopfiella latipes (N. Lundq.) Malloch \& Cain, Can. J. Bot., 49: 876 (1971); (Fig. 18)

Ascomata: $120-700 \mu \mathrm{m}$ in diam.; Asci: $80-120 \mathrm{x}$ 12-18 $\mu \mathrm{m}$; Ascospores: biseriate, ellipsoidal, becoming 1-septate in the lower third; slightly constricted at the septum; larger upper cell 16$22 \times 10-13 \mu \mathrm{m}$, ellipsoidal, apex conical or abonate, base truncate, olivaceous to brown, thin-walled, smooth, with a apical germ pore, smaller lower cell 4-8 $\mu \mathrm{m}$ long, 3-7 $\mu \mathrm{m}$ in diam., broadly cylindrical, apex truncate, base broadly rounded, hyaline, at maturity without cytoplasm; the base and one side of the lower cell thin-walled, collapsing, and giving it a cuplike shape; collapsed lower cell appearing triangular in lateral view.

Habitat:- On submerged wood, Bhandardara dam, Pravara river, 24 August 2014.

Distribution in India:- Marine Habitats:- West Coast:- Gujarat, Maharashtra, Karnataka, Pondecherry (Mahe); East Coast:- T.N., A.P. (see Borse et al., 2012, 2013).

Freshwater habitats:- Tamil Nadu: (Udaiyan, 1989; Udaiyan and Manian, 1991b); Karnataka: (Ramesh and Vijaykumar, 2000, 2006; Sridhar et al., 2010, 2011a); Maharashtra: On subme rged wood (Patil, 2012).

Table No. 1. Comparison of type species and present collection

\begin{tabular}{|l|l|l|}
\hline Particulars & $\begin{array}{l}\text { Paoayen sis lignicola Cabanela, } \\
\text { Jeewon \& K.D. Hyde }\end{array}$ & Paoayensis sp. \\
\hline Ascomata & $\begin{array}{l}\text { Ascomata: 546-626 } \mu \mathrm{m} \text { high, } \\
520-586 \mu \mathrm{m} \text { diam. }\end{array}$ & $\begin{array}{l}700-1000 \mu \mathrm{m} \text { high, } \\
800-1000 \mu \mathrm{m} \text { diam. }\end{array}$ \\
\hline Asci & $45-130 \times 13-35 \mu \mathrm{m}, 2-6$ spored & $85-170 \times 40-65 \mu \mathrm{m}, 4-8$ spored \\
\hline Ascospores & $41.9-79.9 \times 67-74.4 \mu \mathrm{m}$ & $50-80 \times 20-38 \mu \mathrm{m}$ \\
\hline References & Cabanela et al., (2007). & This study \\
\hline
\end{tabular}

Table No. 2. List of Freshwater Ascomycetes from Ahmednagar District with substrata. (SL- Submerged le aves: 01, SW-Submerged wood: $17 \mathrm{sp}$.)

\begin{tabular}{|c|l|c|c|}
\hline Sr. No. & \multicolumn{1}{|c|}{ Name of the fungus } & S L & SW \\
\hline 1 & Aniptodera chesapeaken sis She arer \& M.A. Miller & - & + \\
\hline 2 & Aniptodera inflatiascigera K.M. Tsui, K.D. Hyde \& Hodgkiss & - & + \\
\hline 3 & Annulatascus hongkongen sis Ho et al. & - & + \\
\hline 4 & Annulatascus palmie tensis Goh, K.D. Hyde \& Hodgkiss & - & + \\
\hline 5 & Ascosacculus heterogattulata (S.W. Wong et al.) J. Campb. et al. & - & + \\
6 & Cercophora sp. & - & + \\
\hline 7 & Natantispora retorquens (Shearer \& J.L. Crane) J. Campb. et al. & - & + \\
\hline 8 & Neomassariosphaeria typhicola (P. Karst.) Yin et al. & + & - \\
\hline 9 & Panorbis viscosus (I. Schmidt) J. Campb. et al. & - & + \\
\hline 10 & Paoayensis sp & - & + \\
\hline 11 & Savoryella aquatica K.D. Hyde & - & + \\
\hline 12 & Savoryella fusiformis W.H. Ho, K.D. Hyde \& Hodgkiss & - & + \\
\hline 13 & Savoryella grandispora K.D. Hyde & - & + \\
\hline 14 & Savoryella lignicola E.B.G. Jones \& R.A. Eaton & - & + \\
\hline 15 & Savoryella limnetica H.S. Chang \& S.Y. Hsieh & - & + \\
\hline 16 & Savoryella verrucosa Minoura \& T. Muroi & - & + \\
\hline 17 & Zopfiella karachien sis (S.L. Ahmed \& Asad) Guarro & - & + \\
\hline 18 & Zopfiella latipes (N. Lundq.) Malloch \& Cain & - & +
\end{tabular}

\section{Results and Discussions:}

A list of 93 species (including 25 species of Chaetomium) of Fre shwate $r$ Ascomyce tes which have been identified to species level is provided by Borse et al. (2014b). According to Cai et al. (2014) Chaetomium, the most specious ge nus recorded from freshwater habitats all over the world, none of which have been described originally from freshwater, and thus may not be necessarily be true aquatic species, and hence not included in this paper. The most specious genera in India are Savoryella with (6 sp.), Leptosphaeria (4 $\mathrm{sp}$.$) , Zopfiella (4 \mathrm{sp}$.), Aniptodera (4 sp.), Annulatascus (3 sp.), Lophiostoma (3 sp.), Pleospora (2 sp.) and Jahnula (2 sp.). Some common FWA such as Aniptodera chesapeakensis Shearer \& Miller, Natantispora retorquens (Shearer \& J.L. Crane) J. Campb. et al., Panorbis viscosus (I. Schmidt) 
J. Campb. et al., Savoryella aquatica K.D. Hyde, $\&$ Cain can be found at nearly every site investigated in Ahmednagar district. Most records of FWA were from states of Tamil Nadu (46 sp.), Karnataka (33 sp.), and Maharashtra (18 sp.), represent intensity of studies.

Studies on the FWA in Ahmednagar district have yielded 18 species belonging to ten genera. Out of which, 17 species were encountered on submerged decaying woody debris and one species on submerged decaying leaves of Typha angustata Chaub. and Bory. Aquatic Ascomyctes described by Tilak and Kulkarni (1974) from Maharashtra are not accepted as FWA as they were collected on living leaves of Typha angustata Chaub. and Bory. The species: Aniptodera chesapeakensis Shearer \& M.A. Mill., Natantispora retorquens (Shearer \& J.L. Crane) J. Campb. et al., Panorbis viscosus (I. Schmidt) J. Campb. et al., Savoryella lignicola E.B.G. Jones \& R.A. Eaton, Zopfiella latipes (N. and Zopfiella latipes (N. Lundq.) Malloch Lundq.) Malloch \& Cain were recorded from both marine and freshwater habitats in India (Borse, et al., 2012, 2013b, 2014b).

As aquatic habitats are increasingly altered and degraded, it is imperative that the freshwater fungal species of the remaining high quality aquatic habitats be characterized and isolated. Such baseline information is essential to understand the role of fungi in aquatic habitats and how fungi could be used in the remediation of damaged aquatic habitats. It is clear those additional collections from worldwide, especially in tropical areas and along altitudinal gradients, are needed to fully characterize the biodiversity, geographical distribution pattern, systematics and evolution of freshwater Ascomycetes (Jones et al., 2014). In summary, we hope that the information presented herein will prompt future studies to document Freshwater Ascomycetes of India.

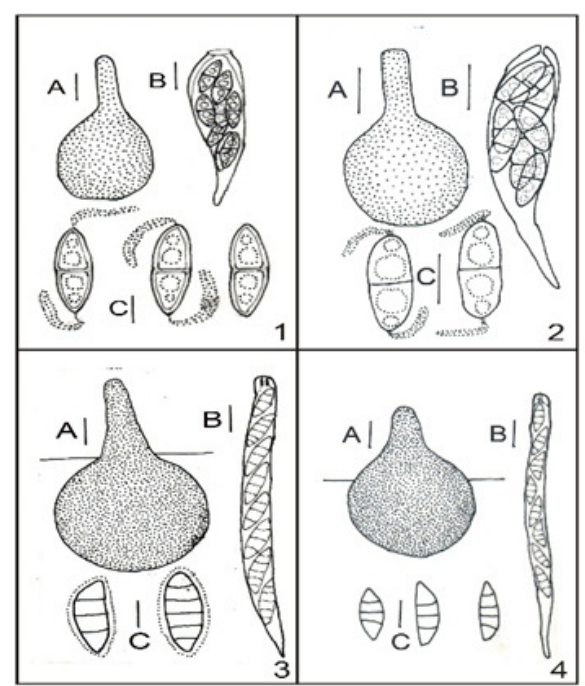

Plate. I

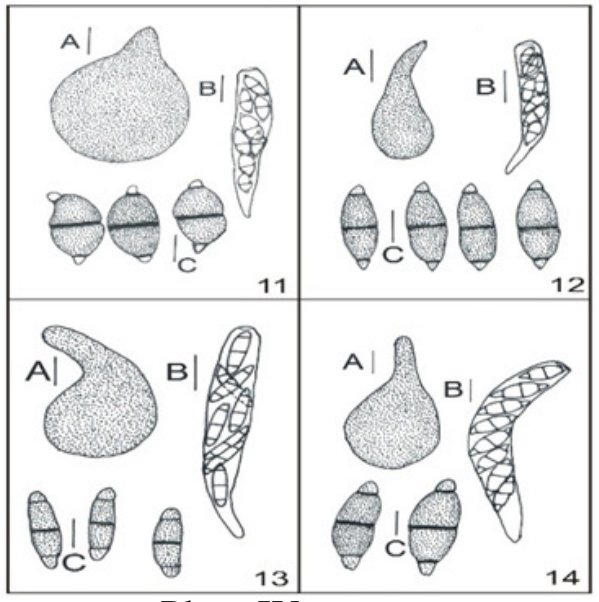

Plate. IV

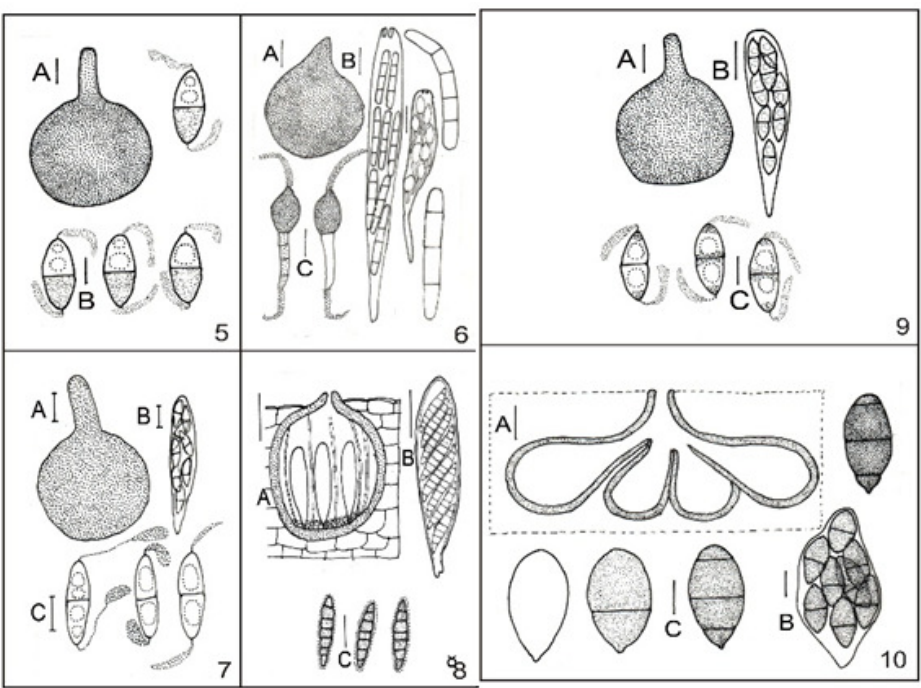

Plate. II

Plate. III

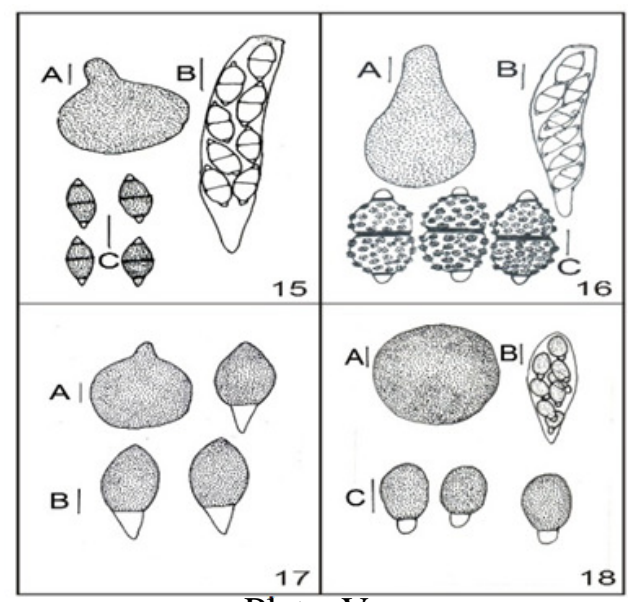

Plate. V 


\section{Acknowledgements:}

Authors are thankful to the Chairmen, N.S. Sans tha, Dhule, Maharshtra' Principal and Management of M. V. P. Ssamj's Arts, Sci. and Comm. college, Ozar (Mig), Nashik M.S); K. A. M. Patil Arts, Comm. and Sci. college, Pimpalner, Dhule (M.S.); Arts, Sci. and Comm. college, Rahuri, Dist.- Ahmednagar (M.S.) for providing laboratory facilities. We are thankful to Dr. Angel Aguirre-Sanchez and authorities of Smithsonian Tropical Research Institute, Washington, DC, USA for sending rare re search articles on freshwater Ascomycetes.

\section{References:}

Agarwal, G.P., Hasija, S.K., Agrawal, P. \& Pandey, A.K. (1991) Fungi associated with submerged de caying leaves and twigs from Jabalpur. Proc. Nat. Acad. Sci., India, 61: 121-125.

Borse B.D. \& Pawara C.M. (2007) Fresh water Ascomycetes from North Maharashtra-I: Bioinfolet, 4: $107-110$

Borse, B.D. \& Patil, V.R. (2015) Aquatic fungi from Buldhana district (M.S., India)-IV. Ascomycetes. International J. Sci. \& Res., 4: 2346-2350.

Borse, B.D., Borse, K.N., Pawar, N.S. \& Tuwar A.R. (2012) "Marine Fungi of India (Monograph)", Broadway Book Centre Publishers and Distributors, Panjim, Goa, pp. 1-471.

Borse, B.D., Borse, K.N., Pawar, N.S. \& Tuwar A.R. (2013) Marine fungi from India -XII: A revised check list. Ind. J. Geo-Marine Sci., 42: 110-119.

Borse, B.D., Borade, D.S. \& Patil, S. Y. (2014a) Freshwater Higher Fungi from Ahmednagar district (M. S., India) - I: The genus Annulatascus. Geobios, 4 1: 55-61.

Borse, B.D., Patil, S.Y., Patil, V.R., Pawara, S.M. \& Borse, K.N. (2014b) Checklist of freshwater Ascomycetes in India. J. Mycopath. Res., 52: 279 284.

Borse B.D., Patil, V.R., Wagh, S.N., Borade, D.S. \& Kambale, V.M. (2015) Freshwater higher fungi from Maharashtra -II: Ascomycetes. Weekly Sci. Res. J., 3 (7): 1-4.

Cabanela, M.V., Jeewon, R., \& K. D. Hyde (2007) Paoayensis lignicola gen. et sp. nov., Cryptogamie Mycologie, 28: 303-310.

Cai, L., Hu, D.M., Liu, F., Hyde, K.D., \& Jones, E.B.G. (2014) The molecular phylogeny of freshwater Sordariomycets and discomycetes. In: "Freshwater Mycology and Fungal-Like Organisms", Walter de Gruyer, GmbH, Berlin, Gemany, pp. $47-$ 71.

Ingold, C.T. (1951) Aquatic Ascomycetes: Ceriospora caudae suis $\mathrm{n}$. sp. and Ophiobolus typhae. Trans. Br. Mycol. Soc., 34: 210-215.

Ingold, C.T. (1954) Aquatic Ascomycetes: Discomycetes from lakes. Trans. Br. Mycol. Soc., 37: 1-18.
Ingold, C.T. (1955) Aquatic Ascomycetes: further from the English lake District. Trans. Br. Mycol. Soc., 38: 157-168.

Ingold, C.T. \& Chapman, B. (1952) Aquatic Ascomycetes: Loramyces juncicola Weston and $L$. macrospora n. sp. Trans. Br. Mycol. Soc., 35: 268272.

Jones, E.B.G., Hyde, K.D. \& Pang, K.L. (eds.) (2014) "Freshwater Mycology and Fungal-Like Organisms", Walter de Gruyer, GmbH, Berlin, Germany, pp. 1-496.

Luo, J., Yin, J., Cai, L., Zhang, K. \& Hyde, K.D. (2004) Freshwater fungi in a Lake Dianchi, a heavily polluted lake in Yunnan, China. Fungal Diversity, 16: 93-112.

Manoharachary, C. (1972) First record of Eleutherascus lectardii from India. Curr. Sci., 41: 892.

Manoharachary, C. \& Rama Rao, P. (1972) Subbaromyces aquaticus, a new Ascomycete from India. Hydrobiologia, 49: 745-749.

Natarajan, K. \& Udaiyan, K. (1978) Cooling tower fungi in India. International Biodeterior. Bull., 14: 85-87.

Patil, S.Y. (2012a) Freshwater Ascomycetes from North Maharashtra - III. International Multidisciplinary Res. J., 2: 18-21.

Patil, S.Y. \& Borse, B. D. (2011a) Diverssity of Savoryella Jones et Eaton from North Maharashtra. J. Eco-biotechnology, 3: 25-28.

Patil, S.Y. \& Borse, B.D. (2012a) Fre shwater Ascomycetes from North Maharashtra - II. Current Botany, 3: 1-4.

Patil, S.Y. \& Borse, B.D. (2012b) Fre shwater Ascomycetes from North Maharashtra - IV. Current Botany, 3: 7-10.

Patil, V.S. \& Borse, B.D. (2015e) Freshwater Ascomycetes from Tapi District (Gujarat, India). Global J. Res. Analysis, 4: 64-67.

Ramesh, Ch. (2002) Seasonal occurrence of water borne fungi in different streams of Uttar Kannada region, Karnataka stare, India. Kavaka, 30: 31-52.

Ramesh, Ch. \& Vijaykumar, S. (2000) Seasonal occurrence of water-borne fungi in Panda stream, Uttara Kan nada region, Karnataka. In: "Ecology of Fungi", (eds. Bhat, D.J. \& Raghukumar, S.), Goa University, Goa, India, pp. 21-27.

Ramesh, Ch. \& Vijaykumar, S. (2004) Physiological studies of some water-borne fungi isolated from Uttar Kannada region, Karnataka, India. Kavaka, 32: 123-144.

Ramesh, Ch. \& Vijaykumar, S. (2005) Species diversity of running freshwater bodies of Uttara Kannada region of Karnataka, India with reference to water-borne conidial fungi. In: "Emerging trends in Mycology, Plant Pathology and Microbial Biotechnology", (eds. Bhagyanarayana et al.), B.S. Pub. Hyderabad, India, pp. 609-626.

Ramesh, C H. \& Vijaykumar, S. (2006) Observation of water-borne fungi of Uttara 
Kannada region. In: "Resent mycological researches" (ed. Sati, S.C.), IK International Publishing House, New Delhi, pp. 61-76.

Shearer, C.A. (1993) Freshwater Ascomycetes. Nova Hedwigia, 56: 1-33.

Sridhar, K.R., Karamchand, K.S. \& Hyde, K.D. (2010) Wood-inhabiting filamentous fungi in highaltitude streams of the Western Ghats by damp incubation and bubble chamber incubation. Mycoscience, 51: 104-115.

Sridhar, K.R., Arun, A.B., Maria, G.L. \& Madhyastha, M.N. (2011a) Diversity of fungi on submerged leaf and woody litter in river Kali, southern India. EVRJ, 5: 1-14.

Sudheep, N.M. \& Sridhar, K.R. (2011) Diversity of lignicolous and Ingoldian fungi on woody litter from the River Kali (Western Ghats, India). Mycology, 2: 98-108.

Thomas, K. (1996). Australian fre shwater fungi. In: "Introductory volume to the fungi (Part-2). Fungi of Australia". Australian Biological Resources Study, Canberra, Australia, pp. 1-37.

Tilak, S.T. \& Kulkarni, R.L. (1974) Aquatic Ascomycetes from India. Beihefte zur Nova Hedwigia, 47: 453-457.

Udaiyan, K. (1989) Some interesting ascomycetes from water cooling towers. Kavaka, 17: 11-16.

Udaiyan, K. (1991) Some in teresting Hyphomyce tes from the industrial water colling towers of Madras. J. Econ. Tax. Bot, 15: 627-647.
Udaiyan, K. \& Hosagoudar, V.S. (1991) Some interesting fungi from the industrial water cooling towers of Madras-II. J. Econ. Tax. Bot., 15: 649666.

Udaiyan, K. \& Manian, S. (1991a) Fungi deteriogens from preservative treated service timber packing in water cooling towers. Inte mational Biodeteri. Bull., 27: 275-279.

Udaiyan, K. \& Manian, S. (1991b) Fungi colonizing wood in the Cooling tower water system at the Madras fertilizer company, Madras, India. Inte mational Biodeteri. Bull., 27: 351-371.

Udaiyan, K., Hosagoudar, V.S. \& Manian, S. (1993) Some interesting fungi from the industrial water cooling towers of Madras III. The genus Chaetomium Kunze ex Fries. J. Econ. Tax. Bot, 17: 121-137.

Volkmann-Kohlmeyer, B. \& Kohlmeyer, J. (1996) How to prepare truly permanent microscopic slides. Mycologist, 10: 107-108.

Wong, M.K.M., Goh, T.K., Hodgkiss, I.J., Hyde, K.D., Ranghoo, V.M., Tsui, C.K.M., Ho, W.H., Wong, S.W. and Yuen, T.C. (1998a) The role of fungi in freshwater ecosystems. Biodivers. Conserv., 7: 1187-1206.

Zhang, H., Jones, E.B.G., Zhou, D., Bahakali, A.H. \& Hyde, K.D., (2011) Checklist of fre shwater fungi in Thailand. Cryptogamie Mycol., 32: 199-2 17. 